\title{
Monetary policy shocks from the consumer perspective
}

\author{
Edda Claus ${ }^{a, *}$ Viet Hoang Nguyen ${ }^{b, \ddagger}$ \\ ${ }^{a}$ Wilfrid Laurier University and CAMA; \\ ${ }^{b}$ The University of Melbourne
}

\begin{abstract}
Applying a latent factor model to survey data on consumer expectations on economic conditions, unemployment, family finances, and readiness to spend reveals that expectations adjust following a monetary policy shock in the direction predicted by standard models. Further, expectations respond asymmetrically to policy tightening or easing, are slow to move, and are consistent with an income channel of monetary policy. Inflation expectations are at first sluggish, but significantly adjust in the long run, in a way that is consistent with a Delphic effect of policy. Expectations are heterogeneous according to gender, income, and housing status in systematic ways.
\end{abstract}

Keywords: Monetary Policy Shocks, Heterogeneous Consumers, Expectations Formation, Latent Factor Model, Nonlinear Autoregressive Distributed Lag Model.

JEL Classifications: E21, E52.

*Corresponding author: Edda Claus, Department of Economics, Wilfrid Laurier University, 75 University Avenue West, Waterloo, ON, N2L 3C5, Canada, Tel.: 519-884-1970 ext. 4570, Fax: 519-884-0201, E-mail address: eclaus@wlu.ca

${ }^{\dagger}$ We would like to thank Iris Claus and Mardi Dungey for comments and suggestions. We gratefully acknowledge the contribution of the Editor, Ricardo Reis, and two anonymous referees for substantial improvements relative to earlier drafts.

${ }_{\ddagger}^{\ddagger}$ Nguyen acknowledges financial support from the University of Melbourne. 


\section{Motivation}

2 Consumer expectations are key in transmitting monetary policy changes to the overall 3 demand for goods and services, yet there is little empirical evidence for this transmission 4 channel. This paper is the first empirical application that examines the effects of mone5 tary policy shocks on a wide range of consumer expectations. We examine differences in

the immediate and longer run responses in expectations and distinguish between policy tightenings and easings. We disaggregate responses by gender, income, age and home ownership and explore the income effect for net borrowers and net lenders as well as their marginal propensities to consume (MPC). Specifically, we apply a latent factor model to examine immediate responses of consumer expectations and apply a nonlinear autoregressive distributed lag (NARDL) model for the longer run responses. Data are from the 'Consumer Attitudes, Sentiments \& Expectations' (CASiE) survey, the Australian version of the Michigan Survey of Consumers.

We find that consumers update their expectations of economic conditions, unemployment, family finances and readiness to spend immediately following monetary policy shocks. Inflation expectations seem well anchored in the short term and only adjust in the longer term. Overall, the updates in consumer expectations are consistent with economic theory. In addition, our results provide strong evidence of: (i) asymmetric responses to policy tightenings and easings in the short and longer term, (ii) rigidities in expectation adjustments and (iii) the income effect of monetary policy changes. The documented asymmetry could be due to business cycles factors, actual or perceived asymmetry in the transmission of monetary policy, a psychological bias in consumer behavior or a combination of these. It takes about 9 to 12 months for expectations to adjust fully to the initial monetary policy shocks, consistent with the information rigidities in Carroll (2003) and Mankiw, Reis, and Wolfers (2004). The rigidities could be due to sticky information (Mankiw and Reis, 2002), noisy information (Woodford, 2002), rational inattention (Sims, 2003), or the outsourcing of information processing (Carroll, 2003). The income effect of monetary policy shocks is broadly consistent with economic theory. Net borrow- 
ers report a decrease in family finances and net lenders report an increase following an unexpected tightening in monetary policy; both sets of households report the opposite following an unexpected easing. Interestingly, the MPC does not seem larger for net borrowers compared to net savers.

In the longer run, the 'Delphic' component of monetary policy changes seems to dominate where policy easings (tightenings) are seen by consumers as signals of a weakening (strengthening) economy; see Campbell, Evans, Fisher, and Justiano (2012). After about 9 to 12 months, policy easings put downward pressure on consumer expectations of economic conditions and upward pressure on unemployment expectations, despite having opposite effects on impact. A possible explanation for this short-longer run difference is that as consumers update their expectations several months following policy easings, they become increasingly aware of weakening economic conditions and worsening employment prospects.

To study the immediate responses to monetary policy shocks, we apply the latent factor model proposed by Rigobon and Sack (2004) and rely on monetary policy announcements from the Reserve Bank of Australia (RBA) to identify monetary policy shocks. Identifying monetary policy shocks is not trivial. Relying on financial market based measures such as central bank rate futures (Kuttner, 2001) or a narrative approach (Romer and Romer, 2004) are not appropriate as consumer expectations differ significantly from financial market participants (Dräger, Lamla, and Pfajfar, 2016) and public sector forecasters (Mankiw et al., 2004). For identification, the Rigobon and Sack (2004) latent factor model solely relies on the increase in variance of expectations data that occurs on exogenously identified monetary policy days. Since the RBA was an early adopter of inflation targeting with transparent policy dating, this identification scheme is ideally suited for our purposes. To study the longer-run adjustments of expectations, we compute the cumulative dynamic effects from an estimated NARDL model proposed by Shin, Yu, and Greenwood-Nimmo (2014).

Our paper fits into the growing interest in monetary policy from the consumer perspec- 
tive. Carvalho and Nechio (2014) use the Michigan Survey to investigate if US consumers form expectations consistent with the Taylor rule. The authors find that at least some US households form expectations on inflation, interest rates and unemployment that are consistent with the Taylor rule. Dräger et al. (2016) also use the Michigan Survey and find that less than $50 \%$ of respondents form expectations consistent with one of the three concepts: the New Keynesian Phillips curve, the Taylor rule and the income Fisher equation. The authors also find that only $6 \%$ of respondents form expectations consistent with all three concepts. A number of studies have found gender, education, income and age to affect the expectations (e.g. Dräger et al., 2016; Bachmann, Berg, and Sims, 2015) but lifetime experiences (Malmendier and Nagel, 2016) and household financial health and attitudes on household spending (Ehrmann, Pfajfar, and Santoro, 2014) may also be important.

Much of the interpretation of monetary policy changes has focused on financial market analysts (Schmidt and Nautz, 2012) but expectations and interpretations by financial market analysts who spend a large part of their time monitoring and analyzing macroeconomic developments may not be informative for consumer expectations and interpretations. Coibion and Gorodnichenko (2015) find that firms' inflation expectations align more closely with consumer expectations than with those of professional forecasters. Firms are the actual price setters and firms and households negotiate wages. This means that understanding how consumers form inflation expectations could be more informative for understanding actual price and wage developments than investigating how professional forecasters form their views. Eusepi and Preston (2010) demonstrate that if agent expectations are inconsistent with central bank policy, monetary policy may fail to stabilize the macroeconomy even in the presence of a formal inflation target.

An increase in interest rates should improve the finances of households who are net savers and the opposite should be true for net borrowers. The aggregate effect will depend on whether there are more net savers or net borrowers and whether their MPC differs. Further re-distribution may come from the interest rate exposure channel. Auclert 
(2015) demonstrates that the interest rate exposure channel matters in the transmission of monetary policy. Interest rate exposure refers to differences in maturity between assets and liabilities where unhedged interest rate exposures (UREs) is the difference in duration to maturity of total liabilities compared to total assets. Positive (negative) UREs mean shorter (longer) maturities of assets compared to liabilities. A tightening in monetary policy puts downward on the finances of households with a negative URE and puts upward pressure on the finances of households with a positive URE and wealth is transferred from the former to the latter. The interest rate exposure channel is operative even if net household debt is zero.

The paper proceeds as follows. Section 2 describes the CASiE data and how monetary policy days are matched with survey dates. Section 3 gives the two empirical models and Section 4 presents the aggregate estimation results for the immediate and longer run responses. Section 5 presents the responses disaggregated by household characteristics and explores monetary policy transmission to consumption. The paper closes with some final thoughts in Section 6. A description of CASiE including survey questions, supplementary statistics and full estimation results are in the online Appendices.

\section{Data}

To investigate how consumers react to monetary policy shocks and how they subsequently form expectations, we use consumer survey data from the Australian CASiE survey and identify monetary policy changes from announcements by the RBA, Australia's central bank.

\subsection{Consumer Attitudes, Sentiments and Expectations Survey}

The CASiE survey commenced in March 1973 and has been a monthly telephone survey since February 1990. Prior to March 1993 the sample size varied between 1000 to 2500 household but has been a constant 1200 household since. The sample is stratified by 
age, gender and state so that it is representative of the Australian population. Responses are cross-classified by age, gender, state, capital city, education, occupation, household income, work status, voting intentions and home ownership. Cross-classifications by household income and home ownership only started from August 1994. Unlike the Michigan Survey of Consumers, no households are re-interviewed so that the survey is a pure repeated cross-section.1

Households are surveyed in relation to: (i) current family finances (family finances now compared to 12 months ago) (FamFin); (ii) future family finances (family finances in the next 12 months compared to now) (FamFin1y); (iii) short-term economic conditions (next 12 months) (Ecoly); (iv) medium-term economic conditions (next 5 years) (Eco5y); and (v) consumer readiness to spend (a good time for people to buy major household items) (Spend). The survey questionnaire is in the online Appendix A. The answers to the survey questions are ordinal, such as 'better-off'/'good', 'same', 'worseoff'/'bad' or 'don't know'. The responses are cumulated into indexes, one for every question. Each index is constructed as the weighted proportion of optimists (whose answers are 'better-off'/'good') less the weighted proportion of pessimists (whose answers are 'worse-off'/'bad') plus 100. Weights are based on stratification factors from census surveys of the Australian Bureau of Statistics (ABS), and are normalized to sum to 100 percent. Therefore, 100 is the neutral mark where the proportion of optimists equals the proportion of pessimists. By construction, the index is bounded between 0 and 200; at 0 everybody is pessimistic and at 200 everybody is optimistic.

Along with the above core questions, respondents are also questioned on their unemployment expectations (Uemp1y) (unemployment level in the next 12 months) and inflation expectations (Inf1y) (price level in the next 12 months). Uemp1y's ordinal responses are also cumulated into an index where a value greater (lower) than 100 indicates that more people are expecting unemployment to rise (fall). The Uemp1y index was added in 1974 and has been monthly since June 1993. For this paper, monthly ob-

${ }^{1}$ Carvalho and Nechio (2014) and Dräger et al. (2016) use the Michigan Survey. They exclude reinterviews from their samples, so their studied datasets and ours are similar in principal. 
servations prior to June 1993 were constructed by linear interpolation. Monthly growth rates of the Uemp1y index are matched to those of the actual unemployment rate with a lead of four months. The four-month lead is based on the highest correlation between the Uemp1y index and actual unemployment outcomes reported in the ABS's Labour Force Survey.

For inflation expectations, together with the qualitative question on the price level in the next 12 months (up/down/the same), respondents answering 'up'/'down' are asked to give a numerical response. The numerical responses, those selecting 'the same' are coded as 0 , are then compiled into a weighted measure of consumer inflation expectations - the Inf1y index. Similar to Uemp1y, Inf1y have been monthly since June 1993. Prior to June 1993, the data were quarterly with a monthly trial period between November 1991 and December 1992. Since Australia's official inflation data are quarterly, missing monthly values of the Inf1y index prior to June 1993 were linearly interpolated by matching the value of the last month in each quarter with the corresponding quarterly value.

FamFin and FamFin1y, on current and future family finances, give direct information on the income effect of monetary policy changes. Ecoly and Eco5y give information on the effects of monetary policy actions as perceived by households. If households' expectations are consistent with standard macroeconomic theory, stimulative policy actions should feed into perceived upward pressure on economic conditions in 12 months as well as 5 years, while a tightening should have the opposite effect. Spend on 'a good time to buy major household items' maps into the interest rate channel. Bachmann et al. (2015) interpret Spend as a 'readiness to spend' and find that it is sensitive to nominal interest rates. Again, if consumer expectations are in line with standard macroeconomic theory, the upward (downward) pressure on economic activity from a policy easing (tightening) should feed into downward (upward) pressure on Uemp1y but upward (downward) on Inf1y.

Due to variations in the survey prior to March 1990 we chose the sample from March 1990 to May 2015 for the aggregate analysis (all households). Although inflation targeting 
Table 2 gives some descriptive statistics for the seven indexes computed from the seven survey questions. ${ }^{3}$ It reveals several stylized facts. First, respondents are more optimistic about their future family finances than about their current family finances as the mean of the FamFin1y index is greater than that of the FamFin index across all categories. Second, males are generally more optimistic than females as means of their FamFin-Spend indexes are higher than those of female and mean of their Uemp1y index is lower. Similarly, higher income households tend to be more optimistic than lower income ones. When considering only the FamFin and FamFinly indexes, the level of optimism declines with age. By home ownership, renters are more optimistic about their current and future family finances than both mortgagors and outright home owners. Regarding Inf1y, males have lower inflation expectations than females and renters have lower inflation expectations than mortgagors and outright home owners. Inflation expectations decrease as household income levels increase but inflation expectations increase as age increases.

\footnotetext{
${ }^{2}$ Note that the sum of proportions in each category may not add to 100 percent because some respondents do not want to disclose some of their information.

${ }^{3}$ The time series plots of all the indexes are provided in the online Appendix A.
} 
1 The Inf1y statistics by age, gender and income offer similar findings to those in earlier 2 studies; see Souleles (2004).

The empirical results presented in this paper do not seem specific to Australian con4 sumers. We examine if Australian households are aware of the Phillips curve to compare 5 with results in Dräger et al. (2016). Unlike the Michigan survey, CASiE does not include a 6 question about expected interest rates, limiting the possible replications of Carvalho and 7 Nechio (2014) and Dräger et al. (2016). We find that, at the aggregate level, nearly one 8 third of respondents form expectations consistent with the Phillips curve. The younger 9 the age group and the higher the household income, the higher the proportion of respon10 dents forming expectations consistent with the Phillips curve. Both results align with 11 Dräger et al. (2016). The detailed results are presented in the online Appendix B.

12

\footnotetext{
${ }^{4}$ On 5 December 2007, the RBA announced a number of new arrangements for communication to take effect with the February 2008 Board meeting. Among other changes, monetary policy decisions are to be communicated at $2.30 \mathrm{pm}$ on the day of the Board meeting.
} 
and 1 on the third day $\left.\right|^{5}$ Further, 8 monetary policy days were after the end of the survey and these were assigned to the following month. Of these 8 days, on one occasion, the following month (November 2008) also included a change in policy but both changes were decreases in the TCR and were coded accordingly.

Panel A of Table 3 gives monetary policy statistics for the two samples, the longer sample: April 1990 to May 2015 for the aggregate estimations and the shorter sample: September 1994 to May 2015 for the estimations disaggregated by consumer characteristics. There were 67 months with changes in the TCR over the longer sample and 54 months with changes in the shorter sample period. This represents 40 months with rises in the TCR for the longer sample and 27 months with rises for the shorter sample, and 27 months with declines in the TCR for both sample periods. This leaves 235 months without monetary policy changes for the longer sample and 195 months for the shorter sample period so that the overall sample sizes are 322 months and 249 months for the long and short sample periods.

\section{— Insert Table 3 around here}

Table 3 also presents the relative standard deviations of consumer responses. The idea underlying our empirical application is that consumer responses change every month but responses display greater variation in monetary policy months. This additional variation is then attributed to the policy surprises. Table 3 Panel B gives the relative standard deviations for the five core questions, Uemp1y and Inf1y as the ratio of the standard deviations of monetary policy months compared to months without policy changes. A ratio greater than one means that responses vary more in policy months compared to non-policy months.

The table shows that standard deviations are greater in policy months compared to non-policy months for six questions: all five core questions and Uemp1y. The differences vary between about $8 \%$ for future family finance (FamFin1y) and about $44 \%$ for 'good time to buy a major household item' (Spend). The $F$-statistics of the variance ratio test

\footnotetext{
${ }^{5}$ Implicitly we are assuming that survey respondents know about a monetary policy change.
} 
indicate that these differences are significant at the 5\% level for FamFin, Eco1y, Spend and Uemp1y. Given our relatively small sample sizes of monetary policy months, these results support greater variations of responses in monetary policy months. Moreover, if the standard deviations in policy months are not statistically significantly larger than those in non-policy months, the parameter estimates for the factor loadings $\alpha_{i}$ and $\beta_{i}$ on the two monetary policy shocks $m_{t}$ and $n_{t}$ in the latent factor model described below will not be statistically significant. Relative standard deviations for disaggregated data by consumer characteristics are presented in the online Appendix C. Fully anticipated changes in the TCR may have no or very little impact on consumer expectations. As expectations vary more in policy change months than in all other months, this suggests that not all changes in the TCR were fully anticipated over the two estimation periods.

Panel B of Table 3 also gives the relative standard deviation and the variance ratio test for Inf1y, and show that Infly varies less in monetary policy months, though the difference is statistically insignificant. This finding suggests that inflation expectations seem well anchored in the short run. There is also no consistent heterogeneity in changes in inflation expectations in monetary policy months compared to non-policy months. This suggests that the expectations formation process is different for inflation compared to unemployment and the general economic outlook, at least in the short run. For this, we only include Inf1y in the longer run analysis, but not in the analysis of immediate responses.

\section{Empirical framework}

We distinguish between immediate responses to policy shocks and longer run adjustments to allow for the presence of information rigidities in consumer expectations. For the immediate responses, we apply a latent factor model (Rigobon and Sack, 2004) and model the longer run adjustments in an NARDL framework (Shin et al., 2014). In both applications, we allow for asymmetry in the responses to tightening compared to easing policy shocks. 


\subsection{Immediate responses}

Every month, consumers receive news either directly or through media outlets. These news, denoted $a_{t}$, though not directly observed, impact consumer expectations. $a_{t}$ could be economic news; for example, changes in the stock market, the exchange rate and oil prices are widely discussed in the media. In addition, in some months, there will be changes in monetary policy. Sometimes, the change in the TCR will be fully anticipated, but Claus and Dungey (2015) demonstrate that only on very few occasions over our sample period, changes in the TCR were fully anticipated. In general, the change in policy has some element of surprise. That means, in monetary policy months, additional unobserved monetary policy news $m_{t}$ and $n_{t}$ apply where $m_{t}$ is a surprise tightening and $n_{t}$ is a surprise easing. Consumers also adjust their expectations in response to these monetary policy news $m_{t}$ and $n_{t}$. This framework can be translated into a latent factor model where consumer responses are a function of one or more latent factors as follows

$$
\operatorname{ind}_{i, t}=\delta_{i} a_{t}+\lambda_{i} d_{i, t}+\alpha_{i} m_{t}+\beta_{i} n_{t}
$$

\footnotetext{
${ }^{6}$ By definition, the time-series property of $a_{t}$ and $d_{i, t}$ is similar to that of unobserved structural shocks in other structural frameworks such as Structural Vector Autoregression (SVAR) and Dynamic Stochastic General Equilibrium (DSGE). By construction, $m_{t}$ and $n_{t}$ are mutually exclusive stochastic jump processes with unit variance and jumps occurring when the policy rate moves.
} 

and $\beta_{i}$ are indicative of asymmetry. Re-writing equation (1) in matrix form gives

$$
I N D_{t}=\Lambda H_{t}+\Pi m_{t}+\Psi n_{t}
$$

negative value for $\alpha_{i}$ suggests that a tightening puts downward pressure on $i n d_{i, t}$ while a negative value of $\beta_{i}$ suggests that a loosening puts upward pressure on $i_{n d, t}$. Positive values for $\alpha_{i}$ and $\beta_{i}$ suggest the opposite. Given that changes in policy are typically in 25 basis points particularly over the later part of the sample, differing magnitudes for $\alpha_{i}$ where $I N D_{t}$ is a $(p \times 1)$ vector of $p$ indexes $i n d_{i, t}$ at time $t$. $H_{t}$ is a $((p+1) \times 1)$ vector of shocks. Its first row is the common shock and the remaining $p$ rows contain the idiosyncratic shocks. $m_{t}$ and $n_{t}$ are $(1 \times 1)$ vectors of the monetary policy shocks. The matrices $\Lambda, \Pi$ and $\Psi$ contain the factor loadings; $\Lambda$ is $(p \times(p+1))$ and $\Pi$, $\Psi$ are $(p \times 1)$.

We separate policy easings and tightenings to allow for potential asymmetries in responses to policy shocks. Extensive research in psychology is devoted to explaining people's apparent negativity bias which refers to the peculiarity that people tend to react more strongly to bad compared to good news; see e.g. Rozin and Royzman (2001). Baghestani and Kherfi (2008) find asymmetry in consumers' prediction for the direction of change in interest rates between 1984 and 2005 where respondents in the Michigan survey fail to predict accurately falls in the interest rate. Carvalho and Nechio (2014) find some evidence of asymmetry in expected changes in interest rates in response to changes in unemployment, i.e., non-linearity in the coeffiInf1ynt on unemployment in the Taylor rule. Dräger et al. (2016) also find asymmetry in the consumer concept of the Taylor rule. Although technically, distinguishing between tightenings and easings in monetary policy is not the same as allowing for business cycle effects in the effectiveness of monetary policy, the two should be highly correlated. Central banks typically go on tightening and easing cycles in response to business cycle fluctuations so that distinguishing between tightenings and easings also allows for potential business cycle effects of consumer responses. Souleles (2004) finds business cycle effects for consumer inflation expectations where people underestimated the disinflation of the 1980's and 1990's. This 
could be due to asymmetries in people's forecasts and/or asymmetries in the effectiveness of monetary policy; see, Santoro, Petrella, Pfajfar, and Gaffeo (2014) op cit.

It might be desirable to include a third policy factor to account for occasions when monetary policy could have changed on RBA Board meeting days but did not, because unchanged monetary policy may also represent a policy surprise; see Gürkaynak, Sack, and Swanson (2005). There are not enough 'no change policy months' (months when the RBA announced that the TCR would remain unchanged) and 'non monetary policy months' (months when the RBA made no monetary policy announcement) in the sample to allow inclusion of this third monetary policy factor. However, although 'no change policy' often seems to surprise financial markets in the United States, the number of 'no change policy surprises' seems to be small in Australia (Claus and Dungey, 2015). This means that excluding 'no change policy surprises' from the empirical application is not expected to bias the results.

\subsubsection{Identification}

The four sets of news, $a_{t}, d_{i, t}, m_{t}$ and $n_{t}$, are unobservable. They could potentially be proxied by subtracting some form of forecasts from actual outcomes. But choosing appropriate forecasts is not a trivial exercise. Often researchers utilize published private or public sector forecasts but it is not clear how representative these published forecasts are and given the mounting evidence that consumer expectations formation is different than that of professional forecasters, choosing appropriate forecasts becomes even more difficult. An alternative to creating news series, is to utilize the statistical properties of news augmented with the assumptions we have made. Equation (2) can be identified by recognizing that the monetary policy shocks $\left(m_{t}\right.$ and $n_{t}$ ) occur only in exogenously identified monetary policy months and can thus be separated from the common shock, $a_{t}$. The two monetary policy shocks are mutually exclusive and can hence also be exogenously separated. The practical separation of the shocks means that empirical identification can be achieved through the variance-covariance matrix of the $p$ indexes. Using the indepen- 
dence assumption, we can determine three sets of variance-covariance matrices: (i) in non 2 monetary policy months, when $m_{t}=n_{t}=0$, the variance-covariance matrix, $\Omega$ of $I N D_{t}$ 3 is given by

$$
\Omega=\Lambda \Lambda^{\prime}
$$

4 In monetary policy months, (ii) when policy is tightened $(\Delta T C R>0), m_{t} \neq 0$ and $n=0$, 5 the covariance matrix, $\Omega_{M}$ is given by

$$
\Omega_{M}=\Lambda \Lambda^{\prime}+\Pi \Pi^{\prime}
$$

and (iii) when policy is loosened $(\Delta T C R<0), n_{t} \neq 0$ and $m=0$, the covariance matrix, $\Omega_{N}$ is given by

$$
\Omega_{N}=\Lambda \Lambda^{\prime}+\Psi \Psi^{\prime}
$$

The model is estimated using GMM techniques, based on the second moments as 7 specified in equations (3) to (5). In the case of an overidentified model, which occurs 8 when there are six or more indexes, the Hansen (1982) method for combining the generated moment conditions with the number of parameter estimates is implemented. For

\subsection{Longer run responses}

To study the longer run responses, we employ the NARDL framework proposed by Shin et al. (2014). The cumulative dynamic multiplier effects computed from an estimated NARDL model can indicate how consumer expectations adjust in the longer run. The $\operatorname{NARDL}(p, q)$ model is expressed as

$$
P_{t}=\sum_{i=1}^{p} \mu_{i} P_{t-i}+\sum_{i=0}^{q} \chi_{i}^{+} Q_{t-i}^{+}+\sum_{i=0}^{q} \chi_{i}^{-} Q_{t-i}^{-}+\varepsilon_{t}
$$



adjustments in consumers' 12-month ahead expectations.

Equation (6) can be written in an error correction form as

$$
\Delta P_{t}=\rho \xi_{t-1}+\sum_{j=1}^{p-1} \gamma_{j} \Delta P_{t-j}+\sum_{j=1}^{q-1}\left(\varphi_{j}^{+} \Delta Q_{t-j}^{+}+\varphi_{j}^{-} \Delta Q_{t-j}^{+}\right)+\varepsilon_{t}
$$

9

where $P_{t}$ denotes one of the following indexes: FamFin1y, Eco1y, Uemp1y, and Inf1y; $\mu_{i}$ is the autorgressive parameter; $Q_{t}^{+}=\sum_{i=0}^{t} \Delta Q_{i}^{+}$and $Q_{t}^{-}=\sum_{i=0}^{t} \Delta Q_{i}^{-}$are cumulative sums of increases and decreases in the TCR; $\Delta Q_{t}^{+}=\max \left(\Delta Q_{t}, 0\right)$ and $\Delta Q_{t}^{-}=\min \left(\Delta Q_{t}, 0\right)$ denote rate rises and rate cuts, $\Delta Q_{t}$ denotes the change in the TCR at time $t$. The asymmetric effects of increases and decreases in the TCR on expectations are captured in $\chi_{i}^{+}$and $\chi_{i}^{-}$. We focus on FamFin1y, Eco1y, Uemp1y and Inf1y, all of which have the same forecast horizon of the next 12 months. It is then straightforward to compare the where $\rho=\sum_{j=1}^{p} \mu_{j}-1, \gamma_{j}=-\sum_{i=1+1}^{p} \mu_{i}$ for $j=1, \ldots, p-1 ; \xi_{t}=P_{t-1}-\lambda^{+} Q_{t-1}^{+}+$ $\lambda^{-} Q_{t-1}^{-}$is the nonlinear error correction term where $\lambda^{+}=-\chi^{+} / \rho$ and $\lambda^{-}=-\chi^{-} / \rho$ are the associated long-run parameters with $\chi^{+}=\sum_{j=0}^{q} \chi_{j}^{+}, \chi^{-}=\sum_{j=0}^{q} \chi_{j}^{-} ; \varphi_{0}^{+}=\chi_{0}^{+}$, $\varphi_{0}^{-}=\chi_{0}^{-}, \varphi_{j}^{+}=-\sum_{i=j+1}^{q} \chi_{i}^{+}$and $\varphi_{j}^{-}=-\sum_{i=j+1}^{q} \chi_{i}^{-}$for $j=1, \ldots, q-1$. Reliable estimation of equation (7) can be achieved by standard OLS since it is linear in all the parameters. An appropriate selection of lag structure will render the model free from residual serial correlation. The short-run parameters of equation (7) will be contaminated if monetary policy shocks are contemporaneously correlated with other shocks present in $\varepsilon_{t}$. However, Shin et al. (2014) show that the estimated long-run parameters, $\lambda^{+}$and $\lambda^{-}$, are always consistent and uncontaminated despite the potential weak endogeneity of regressors. Instrumental variables can be used to correct the potential endogeneity issue. Since the short-run effects of monetary policy shocks on expectations are properly identified in our latent factor model in equation (1), our focus here is on the longer-run effects and we will proceed with equation (7).

We follow the general-to-specific approach to select the final specification for equation (7). We first estimate equation (7) with $\max (p)=\max (q)=24$ months and then drop all insignificant stationary regressors. As with the latent factor model estimation, 


\section{Estimation results at the aggregate level}

Table 4 gives the immediate responses while Figure 1 plots the cumulative dynamic multiplier effects for the longer run responses at the aggregate level.

\subsection{Immediate responses}

Monetary policy days are divided into days of rises in the TCR when $m_{t}$ applies and falls in the TCR when $n_{t}$ applies so that $m_{t}$ are mostly positive shocks and $n_{t}$ are mostly negative shocks. This means that the expected signs of $\alpha_{\text {FamFin }}$ to $\alpha_{\text {Spend }}$ are negative while $\alpha_{U E}$ is expected to be positive. A policy tightening shock should put downward pressure on expected future financial conditions (if most households are net borrowers), on expected future economic activity and on readiness to spend (or buying intentions), but should put upward pressure on unemployment expectations. Given that $n_{t}$ are mostly negative shocks, the factor loadings on $n_{t}, \beta_{\text {FamFin }}$ to $\beta_{\text {Spend }}$, are also expected to be negative and $\beta_{U E}$ to be positive so that an easing shock put upward pressure on expected future financial conditions, economic activity, and buying intentions but downward pressure on unemployment expectations.

The results in Table 4 suggest that consumers update their expectations on economic

\footnotetext{
${ }^{7}$ For detailed computation of the cumulative dynamic multiplier effects, see Shin et al. (2014) or the accompanied online Appendix D. Full estimation results are provided in the online Appendix E.
} 
activity and unemployment in line with standard macroeconomics. Increases in the TCR $(\triangle T C R>0 ;$ positive shocks) decrease expected economic activity over the next 12 months but decreases in the TCR $(\triangle T C R<0$; negative shocks) raise expected activity over the next 12 months, as demonstrated by $\alpha_{E c o 1 y}<0$ and $\beta_{E c o 1 y}<0$.

\section{Insert Table 4 around here}

Policy tightenings have a small impact on expected economic conditions in the next 5 years (Eco5y) but easings significantly increase the next 5-year outlook. This could reflect an incomplete understanding of macroeconomics, noisy signals or informational stickiness. It seems reasonable that signals are noisier for economic activity 5-years ahead than just 1-year ahead. One might also expect that the 5-year ahead outlook is updated less frequently than the 1-year ahead outlook. An alternative explanation could be that consumers believe in asymmetric effectiveness of policy tightenings versus easings over the longer term. Or the finding could imply that consumers expect the central bank to respond more strongly to a deteriorating economy and downward pressure on prices than an overheating economy and upward pressure on prices. This would be in line with the asymmetries in the Taylor rule found in Carvalho and Nechio (2014) and Dräger et al. (2016).

Changes in unemployment expectations are also in line with economic theory. A tightening in monetary policy increases expected unemployment over the next 12 months $\left(\alpha_{U E}>0\right)$ and an easing decreases expected unemployment $\left(\beta_{U E}>0\right)$. This is in line with Curtin (2003) who finds that Uemp1y, although not fully rational, but are close to rational. The magnitudes of the two factor loadings are different with $\beta_{U E}$ more than twice as large as $\alpha_{U E}$, which points to perceived asymmetries in the Taylor rule.

Table 4 suggests that policy tightenings put downward pressure on the readiness to spend $\left(\alpha_{\text {Spend }}<0\right)$ and easings put upward pressure on the readiness to spend $\left(\beta_{\text {Spend }}<\right.$ $0)$. This is consistent with the interest rate channel of monetary policy and also aligns with Carroll and Dunn (1997) who find a strong negative correlation between Uemp1y and consumer spending. 
The remaining results are less clear. Households declare a decrease in current financial conditions following both a policy tightening and an easing $\left(\alpha_{\text {FamFin }}<0, \beta_{\text {FamFin }}>0\right)$. However, they declare a fall in future financial conditions following a policy tightening and a rise in future financial conditions following an easing $\left(\alpha_{\text {FamFin }}, \beta_{\text {FamFin }}<0\right)$. The latter result is in line with the income effect of the interest rate channel where households are net borrowers.

The finding that a tightening leads to a deterioration in current family finances is consistent with the large net debt position of Australian households. The result that current family finances deteriorate with an easing in monetary policy is unexpected and might be due to the asymmetric response of consumers to monetary policy shocks. Savers, whose income declines with a policy easing may react more strongly, possibly because further easings may be expected or maybe savers have a positive URE so that the returns on assets decline faster than payments on liabilities. Household finances are explored in more detail below.

Overall, the aggregate results suggest asymmetry in the effects of tightening and easing shocks. Policy easings have a stronger impact than tightenings on the short and medium term economic outlook (Eco1y and Eco5y) and on Uemp1y. This asymmetry could be due to business cycles factors, actual or perceived asymmetry in the transmission of monetary policy, a psychological bias in consumer behavior or a combination of these.

For household specific responses, the asymmetry goes in the opposite direction as easings have a smaller impact on current family finances (FamFin) and buying intentions (Spend) than tightenings. This inconsistency could be driven by household heterogeneity as household differences are likely to affect household specific responses more than responses to general economic and labour market outlooks.

\subsection{Longer run responses}

Figure 1 plots the cumulative dynamic multiplier effects at the aggregate level over a 24-month horizon, $h=24$. The results are interpreted as the effects of a unit in- 
crease/decrease in the TCR on expectations. A positive (negative) value of the multiplier effect (measured by index points for FamFin1y, Eco1y, Uemp1y and percentage points for Inf1y) means that policy shocks put upward (downward) pressure on expectations. Figure 1 reveals that there are large adjustments in consumer expectations around 9 to 12 months after shocks in all four questions. This is similar to the findings in Carroll (2003) and Mankiw et al. (2004) who find that consumers update their expectations on average around every 12 months. The direction of short-run effects of policy shocks on FamFin1y and Eco1y are consistent with the results from the latent factor model with rate increases (decreases) immediately lowering (lifting) expectations. The difference in the magnitude of the short-run effects with those from the latent factor model may reflect the weak endogeneity of monetary policy shocks in equation (7).

— Insert Figure 1 around here -

In the longer run, decreases in the TCR do not have any significant effects on expectations about future family finances (FamFin1y) while increases in the TCR lower expectations about future family finances by around 2 index points. If consumer expectations about future family finances translate into actual spending, then increases in the TCR would reduce spending more than decreases would increase it, which is consistent with Auclert (2015). Regarding expectations on short-term economic conditions (Eco1y), both increases and decreases in the TCR lower expectations by around 2 index points in the longer run. The adjustment of Ecoly following rate decreases is interesting: expectations rise instantly following rate decreases, similar to the result from the latent factor model, but gradually decline to a negative longer-run value with the switch from positive to negative value occurring after 9 to 12 months. This could reflect consumers' increasing awareness of weakening economic activity as they update their expectations following rate decreases.

For Uemp1y, increases in the TCR put upward pressure on Uemp1y in the longer run but have no significant instant impact. The short run effect of decreases in the TCR is consistent with the results from the latent factor model where rate decreases lower 
1 Uemp1y instantly. Conversely, in the longer run, rate decreases put upward pressure on 2 Uemp1y. The switch from a negative value (positive effect) to a positive value (nega3 tive effect) is similar to the switch in Ecoly with a significant adjustment at $h=12$ 4 months. These switches are inconsistent with macroeconomic theory but may be consis5 tent consumer expectations formation when policy changes are 'Delphic': as consumers 6 update their expectations following rate decreases, a realization of weakening activity is 7 accompanied by an expected increase in unemployment. Moreover, rate decreases have 8 a stronger short run effect than rate increases, consistent with the results from the latent factor model. In the longer run, however, the effect of rate increases on Uemp1y is stronger (nearly twice as large as that of rate decreases).

Regarding Inf1y, both increases and decreases in the TCR raise Inf1y in the longer run with a stronger effect of rate increases. Moreover, consumers do not seem to respond to rate increases instantly supporting the exclusion of Inf1y from the latent factor model application. The upward pressure of rate increases on Inf1y is counter-intuitive given the strong upward pressure of rate increases on Uemp1y. This result is possibly due to the strong positive relationship between the TCR and Infly in two the recent periods 17 of rate increases: (i) from 2005 to mid 2008 and (ii) from late 2009 to early 2011, both 18 of which witnessed sharp increases in oil prices. The TCR rose from $5.25 \%$ to $7.25 \%$

in the first period and from $3.00 \%$ to $4.75 \%$ in the second period while Infly rose from $4.8 \%$ to $10.8 \%$ and from $6.1 \%$ to $9.0 \%$. Following Coibion and Gorodnichenko (2015)'s explanation for the missing disinflation during the Great Recession, the counter-intuitive effect of rate increases on Inf1y can be driven by the increases in oil prices over these periods. Households adjust their inflation expectations more strongly to changes in oil prices than professional forecasters because gasoline prices are among the most visible prices to consumers and thus households pay particular attention to them when forming expectations of other prices. 


\section{Estimation results by heterogeneous households}

2 Previous studies have shown that household heterogeneity matters in expectations for3 mation, in particular, income, education and age; see Dräger et al. (2016) and Souleles 4 (2004) although Bachmann et al. (2015) find little evidence that demographic factors 5 are important. It might not be surprising that education influences expectations forma6 tion and that more educated agents produce more accurate forecasts and update their 7 information sets more regularly; see Pfajfar (2013). A perhaps more puzzling result is 8 the finding of differences between males and females; see Madeira and Zafar (2015) and 9 Dräger et al. (2016). 
1 for females $\left(\alpha_{\text {FamFin }}, \alpha_{\text {FamFin1y }}, \beta_{\text {FamFin1y }}<0\right)$ with larger absolute magnitudes for the 2 factor loadings than those for males.

For income, responses of the higher income group (over $\$ 80 \mathrm{k}$ ) are most consistent 4 with macroeconomic theory, in line with results for inflation expectations in Armantier, 5 de Bruin, Topa, van der Klaauw, and Zafar (2015). Reported impacts of monetary 6 policy surprises on current and future household financial conditions are consistent with 7 the observation that household debt in Australia is held by the rich (see, Wilkins and 8 Wooden, 2004). Higher income households also exhibit a strong asymmetry in responses 9 to policy tightenings compared to easings and the absolute magnitude of their factor

loadings is considerably larger than that of other income groups. It is not clear what drives this. Perhaps this group is particularly homogenous, and perhaps higher income households (usually with higher education) follow monetary policy developments more closely. Or perhaps, they are more sensitive to policy changes than other income groups due to their greater household debt.

There are considerable differences in responses to monetary policy surprises among the four age groups. Responses of the young (aged 18-34) are the least consistent with standard economic theory. Age groups 35-44 and 45-54 give responses on family finances consistent with positive net debt positions, probably reflecting a high incidence of mortgaged home ownership among these two groups. Also noteworthy is that all four age groups report changes in unemployment expectations roughly in line with economic theory. Perhaps consumers are clearer on what drives unemployment than other economic concepts, in line with results in Conover, Feldman, and Knight (1986).

\subsection{Longer run responses by income}

Figure 2 plots the longer run effects of policy tightenings and easings on expectations of households by income groups. The discussion here focuses on the longer run responses by income that display the biggest difference to the aggregate results. Results by age, home ownership status and gender are in the online Appendix E. Figure 2 shows that increases 
1 in the TCR put stronger downward pressure on expectations about future family finance 2 (FamFin1y) of higher-income households (between $\$ 40 \mathrm{k}-\$ 80 \mathrm{k}$ and above $\$ 80 \mathrm{k}$ ). This is 3 probably because higher income households tend to hold more debt. Regarding expec4 tations about future economic activity (Eco1y), increases in the TCR have a negative 5 effect on the expectations of households with income between $\$ 40 \mathrm{k}-\$ 80 \mathrm{k}$ in the longer6 run but have a positive effect on the expectations of households with income below $\$ 40 \mathrm{k}$.

7 Decreases in the TCR put much stronger upward pressure on Uemp1y of low-income 8 households in the long run, indicating that a weakening in economic activity weighs more 9 heavily on employment prospects of low-income households. Overall, the longer-run ad10 justments of FamFin1y, Eco1y and Uemp1y by income groups suggest that the 'Delphic' 11 component of TCR decreases is stronger than that of TCR increases, especially around 9 to 12 months as consumers update their expectations following the initial shocks.

\subsection{Exploring the transmission to consumption}

Exploring responses that relate to household-specific conditions rather than general economic conditions can give some insights into how monetary policy shocks might be transmitted to household consumption. Here, we investigate whether home ownership affects the perception of the effects of monetary policy shocks. Home ownership is a good indicator of overall net debt positions as Australian households hold comparatively few interest bearing assets directly (see Connolly, Fleming, and Jääskelä, 2012) and the lion's share of household debt is housing debt; the ratio of household debt to disposable income rose from around $50 \%$ in 1990 to around $155 \%$ in 2015 while housing debt rose from about $35 \%$ of disposable income to around $140 \% .9$ In addition, mortgage rates generally move in step with monetary policy ${ }^{10}$ and this seems to be understood by many Australians

${ }^{9}$ Reserve Bank of Australia Statistical Table e02hist.xls available at
http://www.rba.gov.au/statistics/tables/xls/e07hist.xls, accessed 7 July 2015.
${ }^{10}$ Although the correlation between changes in the TCR and changes in mortgage rates is weaker prior
to August 1994, mortgage rates and the TCR are highly correlated over the entire sample period.


Table 6 gives the estimation results when respondents are disaggregated along two dimensions: (1) by home ownership and (2) by gender; income; and age. Home ownership is divided into three groups: respondents who rent, respondents who own their home but with a mortgage and respondents who own their home outright. A peculiarity of the Australian market is that many Australians own real estate as an investment vehicle. So, outright home ownership does not necessarily mean that respondents are mortgage debt free. Around a quarter of home owners who fully own their home have investment property 11 Table 6 reports results on current and future family finances and on readiness to spend (good time to buy), a proxy for the MPC. Full estimation results are in the online Appendix E.

The perceived income effect is broadly in line with standard economic theory. Mortgagors, who would typically have a negative net asset position, generally declare a decrease in current family finances following an unexpected tightening in monetary policy $\left(\alpha_{i}<0\right)$ and a rise in current family finances following an unexpected easing $\left(\beta_{i}<0\right)$. Mortgagors with household income between $\$ 40 \mathrm{k}$ and $\$ 80 \mathrm{k}$ stand out by reporting a rise in current family finances following a tightening in policy and a decline in current family finances following an easing. It is not entirely clear what drives this result.

Again, consistent with economic theory, for renters, an unexpected policy tightening tends to be perceived as putting upward pressure on current family finances while an

\footnotetext{
${ }^{11}$ See the quarterly St.George - Melbourne Institute Household Financial Conditions Report and Melbourne Institute Household Saving and Investment Report, various issues.
} 
unexpected easing tends to be perceived as putting downward pressure on current family finances. Notable exceptions are low income renters, who could be young people paying off education related debt, and renters aged $55+$. The latter is perhaps a worrying result because it suggests that older respondents have a non-negligible level of net debt and are approaching retirement without net savings. An analogous conclusion comes from home owners in the same age bracket who also report a decline in current family finances following a surprise tightening in policy and a rise in family finances following a surprise easing in policy. Compulsory superannuation was only introduced in Australia in 1992. In particular for older Australians, real estate is an important vehicle for retirement savings. Very large returns in real estate investment since the early 2000's might be a driver in this apparent excessive levering of people close to retirement. Real estate investment may also be a factor in the reported downward pressure on family finances following tightenings in policy and upward pressure following easings in policy of other home owners.

For readiness to spend, household heterogeneity also matters as responses differ by gender, income and age. For mortgagors and home owners, factor loadings are generally negative, suggesting that tightening surprises put downward pressure on the readiness to spend and easing surprises have the opposite effect. This is consistent with the theoretical relationship between interest rates and household consumption. For renters, results are not as consistent as both surprise tightenings and easings put downward pressure on the readiness to spend. Perhaps the income effect of the policy move influences households' readiness to spend. Overall, the results point to asymmetry in the responses to policy tightenings and easings.

Interestingly Table 6 does not point to a higher MPC of net borrowers compared to net savers; factor loadings for mortgagors are not larger than those for renters and owners. This could be a direct result of the 2008-09 financial crisis. There was a marked change in attitudes towards spending and saving during and in the aftermath of the financial crisis. Although job losses were moderate and Australia never experienced a recession, precautionary savings rose substantially over that period, probably in part driven by 
concerns over the very large mortgage debt held by households ${ }^{12}$ This may also be the reason why results for mortgagors display less consistency than results for renters and owners.

Responses on future family finances are not as consistent as those on current family finances. Unexpected policy tightenings tend to increase future family finances of renters $\left(\alpha_{i}>0\right)$ but tend to decrease finances of mortgagors and owners $\left(\alpha_{i}<0\right)$. This is in line with standard economic theory. However, reactions to unexpected policy easings tend to increase future family finances of renters and mortgagors $\left(\beta_{i}<0\right)$ but tend to decrease future family finances of home owners $\left(\beta_{i}>0\right)$. Ignoring differences in maturity on assets and debt, standard economic theory tells us that expectations on family finances are the sum of expected real family finances and inflation expectations. So, responses on future family finances implicitly incorporate expectations on real income and on inflation. In light of previous findings that consumer understanding of one economic concept does not necessarily mean understanding of other economic concepts (see Dräger et al. 2016) it is difficult to speculate on the potential drivers of the inconsistenInf1ys.

\section{Final thoughts}

This paper is first at exploring in detail the consumer expectations channel of monetary policy shocks. Given well documented rigidities in consumer expectations, theoretical assumptions and empirical outcomes of consumer responses to monetary policy may not align leading to unexpected and perhaps undesired policy outcomes. Overall, consumer expectations align with theoretical predictions but our empirical applications produce a number of interesting findings all of which are exciting avenues for future research.

Consumers adjust expectations on economic activity, unemployment, family finances and readiness to spend immediately following a monetary policy shock. Inflation expectations are initially anchored and only respond in the longer run. It is not clear whether this difference in timing is the result of the central bank's credibility in achieving infla-

\footnotetext{
${ }^{12}$ see St.George - Melbourne Institute Savings Report, various issues.
} 


\section{References}

Armantier, O., de Bruin, W. B., Topa, G., van der Klaauw, W., Zafar, B., 2015. Inflation expectations and behavior: Do survey respondents act on their beliefs? International Economic Review 56 (2), 505-536.

Auclert, A., 2015. Monetary policy and the redistribution channel. mimeo.

Bachmann, R., Berg, T., Sims, E. R., 2015. Inflation expectations and readiness to spend: Cross-sectional evidence. American Economic Journal: Economic Policy 7 (1), 1-35.

Baghestani, H., Kherfi, S., 2008. How well do U.S. consumers predict the direction of change in interest rates? The Quarterly Review of Economics and Finance 48 (4), 725-732.

Campbell, J. R., Evans, C. L., Fisher, J. D., Justiano, A., 2012. Macroeconomic effects of Federal Reserve forward guidance. Brookings Papers of Economic Activity (Spring 2012), 269-298.

Carroll, C. D., 2003. Macroeconomic expectations of households and professional forecasters. The Quarterly Journal of Economics 118 (1), 269-298.

Carroll, C. D., Dunn, W. E., 1997. Unemployment expectations, jumping (S,s), triggers and household balance sheets. In: Bernanke, B. S., Rotemberg, J. (Eds.), NBER Macroeconomics Annual. MIT Press, Cambridge MA, pp. 165-217.

Carvalho, C., Nechio, F., 2014. Do people understand monetary policy? Journal of Monetary Economics 66 (September 2014), 108-123.

Claus, E., Dungey, M., 2015. Can monetary policy surprise the market? CAMA Working Paper 2015-5.

Coibion, O., Gorodnichenko, Y., 2015. Is the Phillips curve alive and well after all? Inflation expectations and the missing disinflation. American Economic Journal: Macroeconomics 7 (1), 197-232.

Connolly, E., Fleming, F., Jääskelä, J., 2012. Households' interest-bearing assets. Reserve Bank of Australia Bulletin December Quarter 2012, 23-32. 
Conover, P. J., Feldman, S., Knight, K., 1986. Judging inflation and unemployment: The origins of retrospective evaluations. The Journal of Politics 48 (3), 565-588.

Curtin, R. T., 2003. Unemployment expectations: The impact of private information on income uncertainty. Review of Income and Wealth 49 (4), 539-554.

Dräger, L., Lamla, M. J., Pfajfar, D., 2016. Are consumer expectations theory-consistent? The role of central bank communication and news. European Economic Review 85 (June 2016), 84-111.

Ehrmann, M., Pfajfar, D., Santoro, E., 2014. Consumer attitudes and the epidemiology of inflation expectations. Bank of Canada Working Paper 2014-28.

Eusepi, S., Preston, B., 2010. Central bank communication and expectations stabilization. American Economic Journa; 2 (3), 235-271.

Gürkaynak, R. S., Sack, B., Swanson, E., 2005. Do actions speak louder than words? The response of asset prices to monetary policy actions and statements. International Journal of Central Banking 1 (1), 55-93.

Hansen, L. P., 1982. Large sample properties of generalized method of moments estimators. Econometrica 50 (4), 1029-1054.

Kuttner, K. N., 2001. Monetary policy surprises and interest rates: Evidence from the Fed Funds futures market. Journal of Monetary Economics 47 (3), 5233-544.

Madeira, C., Zafar, B., 2015. Heterogenous inflation expectations and learning. Journal of Money, Credit and Banking 47 (5), 867-896.

Malmendier, U., Nagel, S., 2016. Learning from inflation experiences. Quarterly Journal of Economics 131 (1), 53-87.

Mankiw, N. G., Reis, R., 2002. Sticky information versus sticky prices: A proposal to replace the New Keynesian Phillips curve. Quarterly Journal of Economics 117 (4), 1295-1328.

Mankiw, N. G., Reis, R., Wolfers, J., July 2004. Disagreement about inflation expectations. NBER Macroeconomics Annual 78, 209-270.

Pfajfar, D., 2013. Formation of rationally heterogeneous expectations. Journal of Economic Dynamics and Control 37 (8), 1434-1452.

Rigobon, R., Sack, B., 2004. Impact of monetary policy on asset prices. Journal of Monetary Economics 51 (8), 1553-1575.

Romer, C. D., Romer, D. H., 2004. A new measure of monetary shocks: Derivation and implications. American Economic Review 94 (4), 1055-1084.

Rozin, P., Royzman, E. B., 2001. Negativity bias, negativity dominance, and contagion. Personality and Social Psychology Review 5 (4), 296-320. 
Santoro, E., Petrella, I., Pfajfar, D., Gaffeo, E., 2014. Loss aversion and the asymmetric transmission of monetary policy. Journal of Monetary Economics 68 (November 2014), $19-36$.

Schmidt, S., Nautz, D., 2012. Central bank communication and the perception of monetary policy by financial market experts. Journal of Money, Credit and Banking 44 (2-3), 323-340.

Shin, Y., Yu, B., Greenwood-Nimmo, M., 2014. Modelling asymmetric cointegration and dynamic multipliers in a nonlinear ardl framework. In: Horrace, W. C., Sickles, R. C. (Eds.), Festschrift in Honor of Peter Schmidt: Econometric Methods and Applications. New York (NY): Springer Science \& Business Media.

Sims, C., 2003. Implications of rational inattention. Journal of Monetary Economics $50(3), 665-690$.

Souleles, N. S., 2004. Expectations, heterogeneous forecast errors, and consumption: Micro evidence from the Michigan Consumer Sentiment Surveys. Journal of Money, Credit and Banking 36 (1), 39-72.

Wilkins, R., Wooden, M., 2004. Household Debt in Australia: The looming crisis that isn't. Australian Economic Review 42 (3), 358-366.

Woodford, M., 2002. Imperfect common knowledge and the effects of monetary policy. In: Aghion, P., Frydman, R., Stiglitz, J., Woodford, M. (Eds.), Knowledge, Information, and Expectations in Modern Macroeconomics. Princeton University Press, Princeton. 


\section{Tables and Figure}

Table 1: Average weighted proportions of different household groups (\%)

\begin{tabular}{|c|c|c|c|c|c|}
\hline Category & Stat. & \multicolumn{4}{|c|}{ Group } \\
\hline \multirow[t]{3}{*}{ Gender } & & Male & Female & & \\
\hline & mean & 48.97 & 51.03 & & \\
\hline & s.d. & 0.44 & 0.44 & & \\
\hline \multirow[t]{3}{*}{ Income } & & Under $\$ 40 \mathrm{k}$ & $\$ 40 \mathrm{k}-\$ 80 \mathrm{k}$ & Over $\$ 80 \mathrm{k}$ & \\
\hline & mean & 28.84 & 25.46 & 25.16 & \\
\hline & s.d. & 7.54 & 2.49 & 12.79 & \\
\hline \multirow[t]{3}{*}{ Home Ownership } & & Renter & Mortgagor & Outright Owner & \\
\hline & mean & 20.19 & 34.05 & 43.00 & \\
\hline & s.d. & 2.96 & 3.75 & 2.98 & \\
\hline \multirow[t]{3}{*}{ Age } & & $18-34$ & $35-44$ & $45-54$ & $55+$ \\
\hline & mean & 33.51 & 20.61 & 16.54 & 29.34 \\
\hline & s.d. & 4.13 & 0.51 & 1.92 & 2.72 \\
\hline
\end{tabular}

Notes: The sample is from August 1994 to May 2015. The sum of proportions in each category may not add to $100 \%$ because some respondents do not want to disclose some of their information. 's.d.' denotes standard deviation. 
Table 2: Descriptive statistics of aggregate and disaggregate survey indexes

\begin{tabular}{|c|c|c|c|c|c|c|c|c|}
\hline & unit & $\begin{array}{c}\text { FamFin } \\
\text { index }\end{array}$ & $\begin{array}{c}\text { FamFin1y } \\
\text { index }\end{array}$ & $\begin{array}{l}\text { Ecoly } \\
\text { index }\end{array}$ & $\begin{array}{l}\text { Eco5y } \\
\text { index }\end{array}$ & $\begin{array}{l}\text { Spend } \\
\text { index }\end{array}$ & $\begin{array}{l}\text { Uemp1y } \\
\text { index }\end{array}$ & $\begin{array}{c}\text { Inf1y } \\
\%\end{array}$ \\
\hline \multirow[t]{2}{*}{ All } & mean & 87.32 & 108.81 & 94.73 & 93.02 & 127.07 & 129.77 & 5.82 \\
\hline & s.d. & $11.6^{r}$ & 9.14 & 21.14 & 12.73 & 14.71 & 20.29 & 1.43 \\
\hline \multirow[t]{2}{*}{ Male } & mean & 96.31 & 113.61 & 104.84 & 102.28 & 133.65 & 125.65 & 4.79 \\
\hline & s.d. & 9.71 & 9.83 & 19.10 & 10.77 & 13.27 & 20.60 & 1.05 \\
\hline \multirow[t]{2}{*}{ Female } & mean & 85.87 & 107.15 & 94.45 & 91.07 & 126.21 & 130.01 & 6.49 \\
\hline & s.d. & 9.00 & 8.54 & 15.28 & 9.08 & 14.25 & 17.61 & 1.33 \\
\hline \multirow[t]{2}{*}{ Under $\$ 40 \mathrm{k}$} & mean & 73.57 & 99.13 & 93.72 & 93.39 & 127.84 & 131.25 & 6.77 \\
\hline & s.d. & 8.19 & 10.06 & 15.66 & 10.44 & 12.73 & 17.57 & 1.55 \\
\hline \multirow[t]{2}{*}{$\$ 40 \mathrm{k}-\$ 80 \mathrm{k}$} & mean & 93.90 & 113.64 & 100.54 & 96.22 & 131.81 & 126.67 & 5.36 \\
\hline & s.d. & 14.96 & 11.98 & 18.20 & 10.66 & 15.28 & 20.46 & 1.32 \\
\hline \multirow[t]{2}{*}{ Over $\$ 80 \mathrm{k}$} & mean & 114.10 & 122.70 & 108.18 & 101.30 & 135.00 & 123.29 & 4.48 \\
\hline & s.d. & 15.66 & 13.13 & 20.75 & 11.13 & 16.59 & 22.84 & 1.15 \\
\hline \multirow[t]{2}{*}{ Renter } & mean & 95.78 & 122.07 & 100.54 & 95.88 & 126.02 & 126.40 & 6.16 \\
\hline & s.d. & 10.53 & 10.66 & 16.66 & 11.39 & 14.24 & 18.91 & 1.42 \\
\hline \multirow[t]{2}{*}{ Mortgagor } & mean & 93.38 & 116.39 & 99.21 & 95.76 & 127.18 & 127.09 & 5.32 \\
\hline & s.d. & 11.03 & 10.46 & 17.87 & 10.57 & 16.61 & 19.94 & 1.13 \\
\hline \multirow{2}{*}{$\begin{array}{l}\text { Outright } \\
\text { Owner }\end{array}$} & mean & 86.68 & 99.69 & 99.56 & 97.54 & 134.36 & 129.27 & 5.65 \\
\hline & s.d. & 9.43 & 8.78 & 17.88 & 9.87 & 12.66 & 19.03 & 1.26 \\
\hline \multirow[t]{2}{*}{$18-34$} & mean & 108.71 & 129.75 & 105.94 & 99.35 & 128.87 & 120.69 & 5.29 \\
\hline & s.d. & 10.69 & 9.74 & 16.47 & 10.47 & 15.48 & 18.08 & 1.22 \\
\hline \multirow[t]{2}{*}{$35-44$} & mean & 90.26 & 114.35 & 96.54 & 93.78 & 125.36 & 130.14 & 5.46 \\
\hline & s.d. & 10.49 & 9.83 & 18.45 & 11.49 & 15.52 & 19.77 & 1.13 \\
\hline \multirow[t]{2}{*}{$45-54$} & mean & 82.15 & 104.42 & 94.16 & 92.58 & 127.70 & 133.14 & 5.86 \\
\hline & s.d. & 10.41 & 10.23 & 18.50 & 11.16 & 14.85 & 19.95 & 1.38 \\
\hline \multirow[t]{2}{*}{$55+$} & mean & 75.73 & 88.24 & 97.27 & 97.62 & 134.74 & 131.37 & 6.05 \\
\hline & s.d. & 9.55 & 8.72 & 18.60 & 10.23 & 12.46 & 19.76 & 1.42 \\
\hline
\end{tabular}

Notes: For aggregate indexes (all respondents), the sample is from March 1990 to May 2015. For disaggregate indexes by gender, income, home ownership and age, the sample is from August 1994 to May 2015. 's.d.' denotes standard deviation. 
Table 3: Monetary policy statistics.

Panel A: Number of policy changes (in months) over the samples

\begin{tabular}{|c|c|c|c|c|c|c|c|c|c|c|}
\hline & \multicolumn{2}{|c|}{$\begin{array}{l}\text { Policy } \\
\text { changes }\end{array}$} & \multicolumn{2}{|c|}{$\begin{array}{c}\text { Rise } \\
\text { in TCR }\end{array}$} & \multicolumn{2}{|c|}{$\begin{array}{l}\text { Declines } \\
\text { in TCR }\end{array}$} & \multicolumn{2}{|c|}{$\begin{array}{l}\text { All other } \\
\text { months }\end{array}$} & \multicolumn{2}{|c|}{$\begin{array}{c}\text { Total } \\
\text { sample size }\end{array}$} \\
\hline Sam & long & short & long & shor & long & shol & long & shol & long & short \\
\hline Months & 67 & 54 & 40 & 27 & 27 & 27 & 235 & 195 & 322 & 249 \\
\hline
\end{tabular}

Panel B: Relative s.d. of survey indexes on days with and without policy changes

\begin{tabular}{rccccccc}
\hline & FamFin & FamFin1y & Eco1y & Eco5y & Spend & Uemp1y & Inf1y \\
\hline Relative s.d. & 1.172 & 1.076 & 1.310 & 1.104 & 1.437 & 1.346 & 0.933 \\
F-statistics & 1.374 & 1.158 & 1.716 & 1.219 & 2.065 & 1.812 & 0.870 \\
p-vlaue & 0.045 & 0.214 & 0.002 & 0.144 & 0.000 & 0.001 & 0.746 \\
\hline
\end{tabular}

NotEs: 'long' sample is from March 1990 to May 2015; 'short' sample is from August 1994 to May 2015. 's.d.' denotes standard deviation. F-statistics $\sim F\left(n_{1}, n_{2}\right)$ with $n_{1}=67$ and $n_{2}=235$.

Table 4: Aggregate estimation results - All respondents: Family finances compared to last 12 months (FamFin), family finances next 12 months (FamFin1y), economic conditions next 12 months (Eco1y), economic conditions next 5 years (Eco5y), time to buy major household items (Spend) and unemployment expectations (Uemp1y); standard errors in parenthesis.

\begin{tabular}{ccccc}
\hline \hline & common $\left(a_{t}\right)$ & idiosyn. $\left(d_{i, t}\right)$ & TCR up $\left(m_{t}\right)$ & TCR down $\left(n_{t}\right)$ \\
& $\delta_{i}$ & $\lambda_{i}$ & $\alpha_{i}$ & $\beta_{i}$ \\
\hline FamFin & $3.032^{* *}$ & $-4.329^{* *}$ & $-3.205^{* *}$ & $1.562 * *$ \\
& $(0.139)$ & $(0.181)$ & $(0.129)$ & $(0.213)$ \\
FamFin1y & $3.344^{* *}$ & $3.888^{* *}$ & $-1.035^{* *}$ & $-1.106 * *$ \\
& $(0.153)$ & $(0.222)$ & $(0.382)$ & $(0.157)$ \\
Eco1y & $7.778 * *$ & $3.584 * *$ & $-6.197 * *$ & $-9.448 * *$ \\
& $(0.350)$ & $(0.473)$ & $(0.425)$ & $(0.311)$ \\
Eco5y & $3.959 * *$ & $-4.807 * *$ & $-0.750 *$ & $-4.649 * *$ \\
& $(0.177)$ & $(0.226)$ & $(0.540)$ & $(0.170)$ \\
Spend & $3.629 * *$ & $5.895 * *$ & $-6.117 * *$ & $-3.952 * *$ \\
& $(0.188)$ & $(0.269)$ & $(0.289)$ & $(0.191)$ \\
Uemp1y & $-3.843 * *$ & $-6.386 * *$ & $1.955 * *$ & $5.058 * *$ \\
& $(0.678)$ & $(0.467)$ & $(0.952)$ & $(0.343)$ \\
\hline
\end{tabular}

Notes: Level of significance: ${ }^{* *} 5$ per cent, ${ }^{*} 10$ per cent. The sample period is from April 1990 to May 2015 (due to first difference transformation), consisting of 67 policy change months (= 40 rises + 27 declines in the TCR) +235 all other months giving an overall sample size of 322 months. 


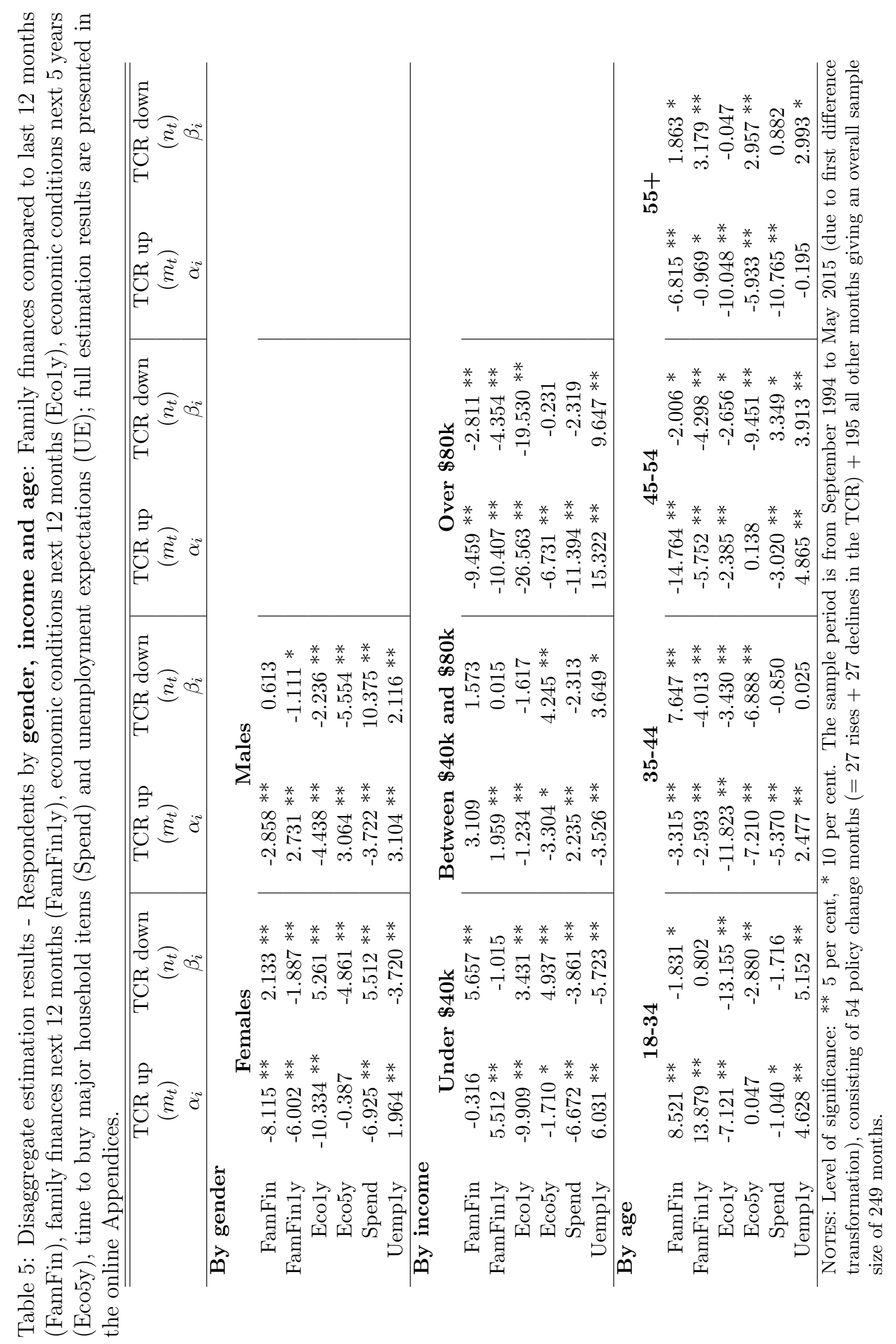


Table 6: Disaggregate estimation results for Family finances compared to last 12 months (FamFin); Family finances next 12 months (FamFin1y) and Time to buy major household items (Spend)- Respondents are disaggregated along two dimensions: (1) by Home ownership: Rent, Own with mortgage (Mor.) and Own outright (Own) and (2) by Gender: Female and Male; by Income: under $\$ 40 \mathrm{k}$, between $\$ 40 \mathrm{k}$ and $\$ 80 \mathrm{k}$, and over \$80k; and by Age: persons aged 18-34, 35-44, 45-54 and 55+; full estimation results are in the online Appendices.

\begin{tabular}{|c|c|c|c|c|c|c|}
\hline & \multicolumn{2}{|c|}{ Current family finances } & \multicolumn{2}{|c|}{ Future family finances } & \multicolumn{2}{|c|}{ Good time to buy } \\
\hline & $\begin{array}{c}\text { TCR up } \\
\left(m_{t}\right) \\
\alpha_{i}\end{array}$ & $\begin{array}{c}\text { TCR } \\
\text { down }\left(n_{t}\right) \\
\beta_{i}\end{array}$ & $\begin{array}{c}\text { TCR up } \\
\left(m_{t}\right) \\
\alpha_{i}\end{array}$ & $\begin{array}{c}\text { TCR } \\
\text { down }\left(n_{t}\right) \\
\beta_{i}\end{array}$ & $\begin{array}{c}\text { TCR up } \\
\left(m_{t}\right) \\
\alpha_{i}\end{array}$ & $\begin{array}{c}\text { TCR } \\
\text { down }\left(n_{t}\right) \\
\beta_{i}\end{array}$ \\
\hline Rent $_{\text {Females }}$ & $-7.760 * *$ & 0.460 & 1.783 & 1.779 & $-5.914 * *$ & $16.958^{* *}$ \\
\hline Rent $_{\text {Males }}$ & 0.357 & $-6.585 * *$ & $9.646 * *$ & 1.284 & $-9.074 * *$ & $-9.121 * *$ \\
\hline Rent $_{\text {Under } \$ 40 \mathrm{k}}$ & $-2.393 *$ & $-5.874 * *$ & $12.365 * *$ & $4.667 * *$ & $-9.326 * *$ & $-16.344 * *$ \\
\hline $\operatorname{Rent}_{\$ 40 \mathrm{k}-\$ 80 \mathrm{k}}$ & $15.099 * *$ & $27.061 * *$ & $16.270 * *$ & $-5.663 * *$ & $-13.612 * *$ & $11.420 * *$ \\
\hline Rent $_{\text {Over } \$ 80 \mathrm{k}}$ & $16.777 * *$ & $9.045 * *$ & 7.366 ** & $-17.814^{* *}$ & 1.807 & $22.469 * *$ \\
\hline Rent $_{18-34}$ & $6.147^{* *}$ & $10.275 * *$ & $-20.954 * *$ & $-4.539 * *$ & $-7.350 * *$ & $16.843^{* *}$ \\
\hline Rent $_{35-44}$ & $-8.077 * *$ & 0.371 & $-13.969 * *$ & 4.067 & $-6.144^{* *}$ & $8.441 * *$ \\
\hline $\operatorname{Rent}_{45-54}$ & $7.385 * *$ & $22.761 * *$ & $15.561^{* *}$ & $-8.859 * *$ & $-11.272 * *$ & $6.749 * *$ \\
\hline Rent $_{55+}$ & $-5.865 * *$ & -1.414 & $3.818^{* *}$ & $-6.284 * *$ & -22.326 ** & $6.472^{* *}$ \\
\hline Mor.Females & $-5.519 * *$ & $-4.386 * *$ & 0.188 & $-2.000 * *$ & -4.399 & $-4.119 * *$ \\
\hline Mor.Males & $-2.055 * *$ & $-2.143 * *$ & 1.248 & $8.708 * *$ & $-4.863 * *$ & $9.829 * *$ \\
\hline Mor.Under $\$ 40 \mathrm{k}$ & $-16.409 * *$ & $-14.672 * *$ & $8.478^{* *}$ & $8.022 * *$ & -0.509 & -1.127 \\
\hline Mor. $\$ 40 \mathrm{k}-\$ 80 \mathrm{k}$ & $5.255 * *$ & $7.814^{* *}$ & $-4.085 * *$ & $-5.402 * *$ & $-5.114 * *$ & $4.261 * *$ \\
\hline Mor. Over $\$ 80 \mathrm{k}$ & -1.206 & $-6.699 * *$ & $4.010 * *$ & $-11.295 * *$ & -0.504 & $-6.186 * *$ \\
\hline Mor.18-34 & 1.048 & 1.528 & $8.524 * *$ & $-3.019 *$ & $-6.525 * *$ & $8.965 * *$ \\
\hline Mor.35-44 & $-8.410 * *$ & $2.999 * *$ & $-4.930 * *$ & $-4.757 * *$ & 0.023 & $3.521 * *$ \\
\hline Mor. 45 & $-1.717 * *$ & $-4.614 * *$ & $-2.369 * *$ & $6.853 * *$ & $-11.893 * *$ & $-6.387 * *$ \\
\hline Mor.55+ & $-11.469 * *$ & $6.789 *$ & $-8.186 * *$ & $-5.994 * *$ & $9.361 * *$ & $-8.974 * *$ \\
\hline Own Females & $-12.424^{* *}$ & $-3.664^{* *}$ & $-15.438^{* *}$ & $-3.658 * *$ & -0.445 & $-2.695^{* *}$ \\
\hline Own Males & $-4.019 * *$ & $-2.812 * *$ & 0.148 & 0.280 & $-6.626 * *$ & $-3.030 * *$ \\
\hline Own $_{\text {Under } \$ 40 \mathrm{k}}$ & $-6.348 * *$ & $1.481 *$ & 0.789 & $9.328 * *$ & $-7.279 * *$ & $-2.941 * *$ \\
\hline $\mathrm{Own}_{\$ 40 \mathrm{k}-\$ 80 \mathrm{k}}$ & $-8.481 * *$ & 0.139 & -1.124 & $-10.484 * *$ & $-4.692 * *$ & $-7.398 * *$ \\
\hline Own Over $\$ 80 \mathrm{k}$ & $5.634 * *$ & $6.189 * *$ & $-12.971 * *$ & -0.194 & -0.182 & $5.761 * *$ \\
\hline $\mathrm{Own}_{18-34}$ & 1.044 & $12.809 * *$ & $-15.704 * *$ & $6.243 * *$ & $6.697 * *$ & $-45.297 * *$ \\
\hline $\mathrm{Own}_{35-44}$ & $7.647 * *$ & $9.541 * *$ & $-10.305 * *$ & $7.992 * *$ & $9.535 * *$ & $-10.373 * *$ \\
\hline $\mathrm{Own}_{45-54}$ & $14.409 * *$ & $3.566 * *$ & $2.466 *$ & $7.231 * *$ & $16.458 * *$ & $15.690 * *$ \\
\hline $\mathrm{Own}_{55+}$ & $-14.838 * *$ & $-1.603 * *$ & $-5.341 * *$ & $-3.504 * *$ & $-18.622 * *$ & $-2.262 * *$ \\
\hline
\end{tabular}

NOTES: Level of significance: $* * 5$ per cent, $* 10$ per cent. The sample period is from September 1994 to May 2015 (due to first difference transformation), consisting of 54 policy change months $(=27$ rises +27 declines in the TCR $)+195$ all other months giving an overall sample size of 249 months. 
Figure 1: Longer-run effects of rate rises and cuts on expectations - aggregate
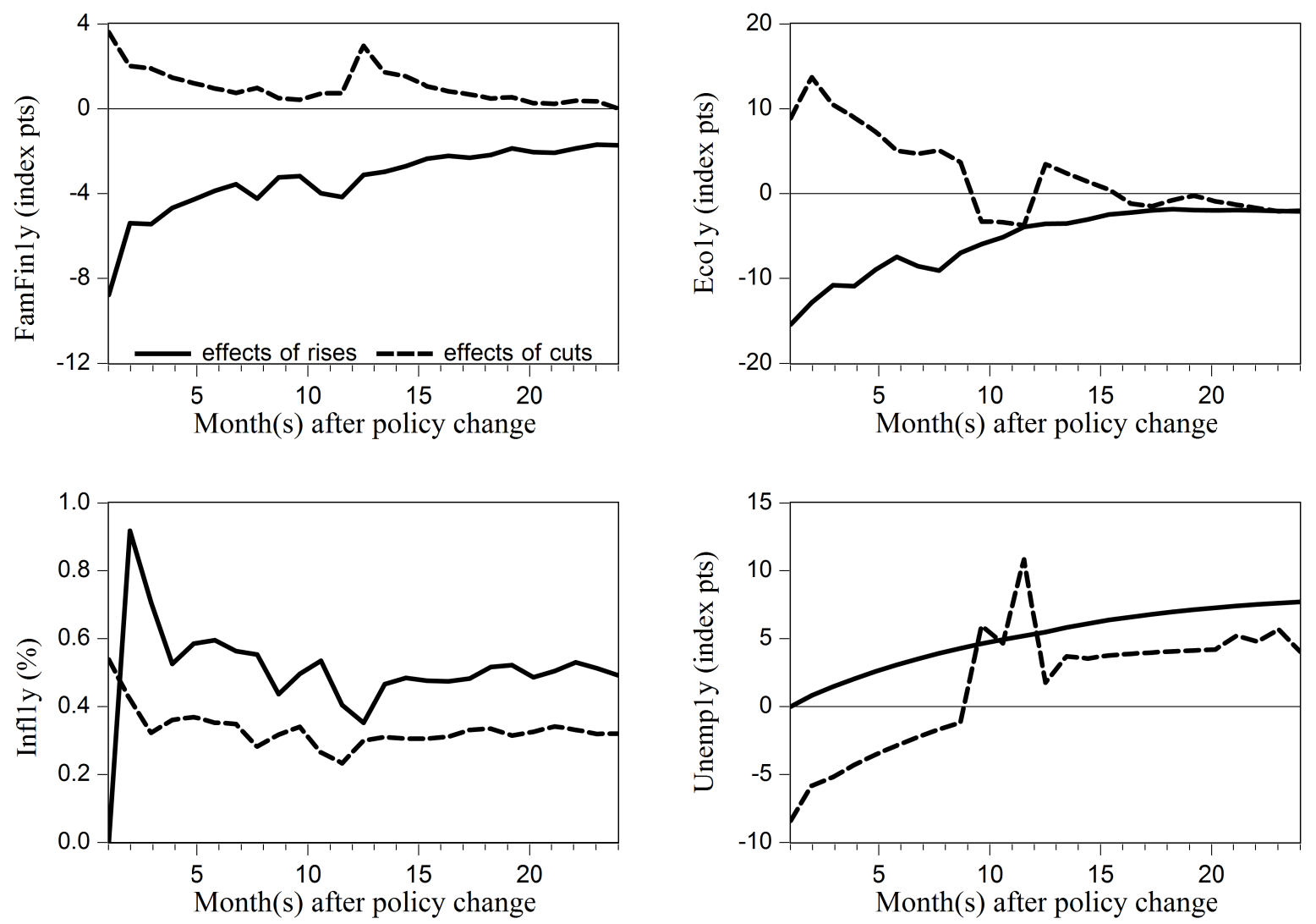

Note: The figure plots the cumulative dynamic multiplier effects computed from the estimated model in equation (7) for all respondents. The sample period is from March 1990 to May 2015, consisting of 67 policy change months $(=40$ rises +27 declines in the TCR $)+235$ all other months giving an overall sample size of 322 months. 
Figure 2: Longer-run effects of rate rises and rate cuts on household expectations - by income
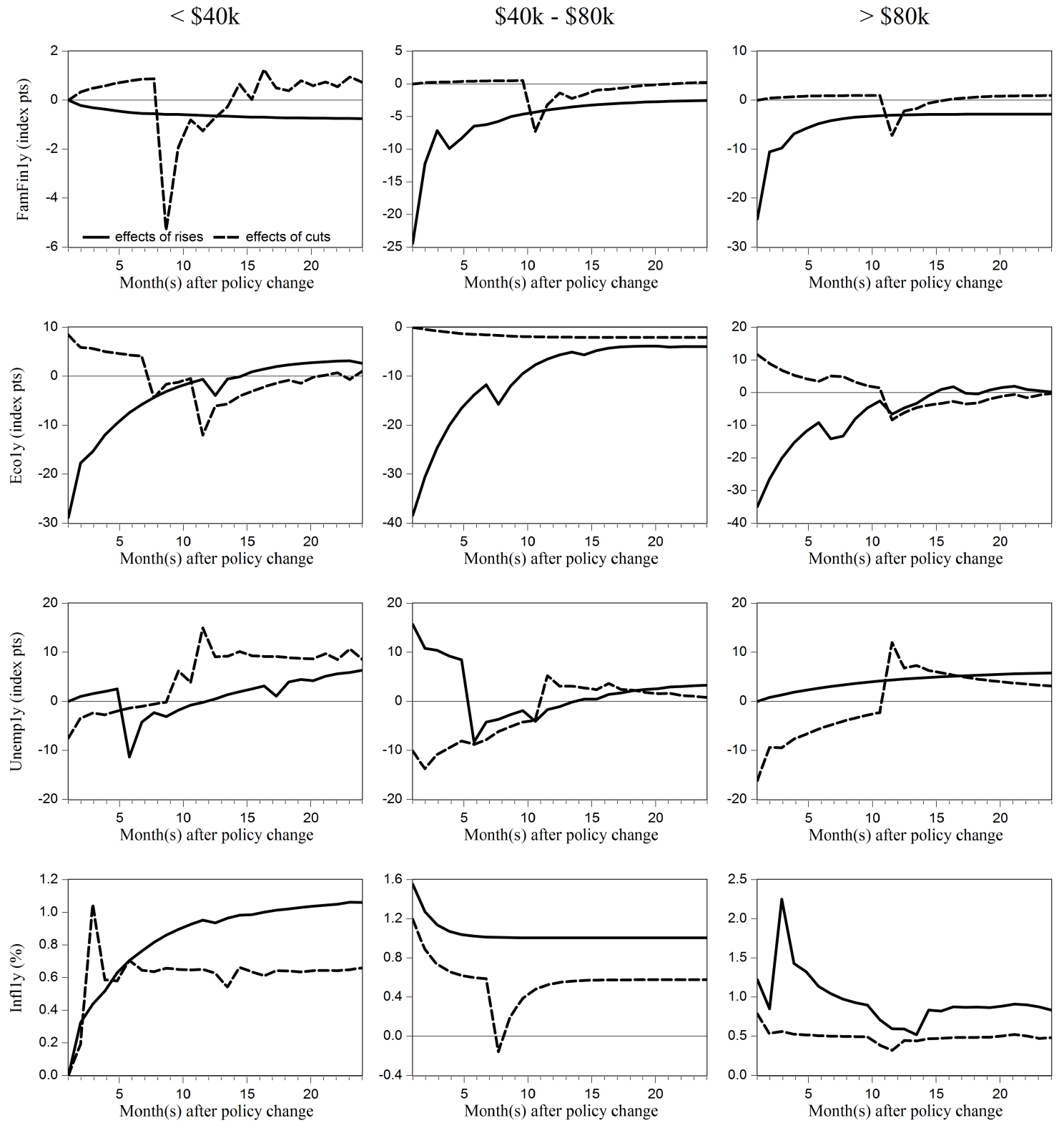

Note: The figure plots the cumulative dynamic multiplier effects computed from the estimated model in equation (7) for respondents disaggregated by household income. The sample period is from August 1994 to May 2015, consisting of 54 policy change months ( $=27$ rises +27 declines in the TCR) +195 all other months giving an overall sample size of 249 months. 